Original research article

\title{
Health literacy and modifiable risk factors of a stroke
}

\author{
Lenka Šedová ${ }^{1}{ }^{*}$, Sylva Bártlová ${ }^{1}$, Andrea Hudáčková ${ }^{1}$, Lucie Havierniková ${ }^{1}$, František Dolák ${ }^{1}$, \\ Svatopluk Ostrý ${ }^{2,3,4}$ \\ ${ }^{1}$ University of South Bohemia in České Budějovice, Faculty of Health and Social Sciences, Institute of Nursing, Midwifery and Emergency Care, \\ České Budějovice, Czech Republic \\ ${ }^{2}$ Department of Neurology, České Budějovice Hospital, České Budějovice, Czech Republic \\ ${ }^{3}$ Department of Neurosurgery of 1st Faculty of Medicine of Charles University and Neurooncological Clinic of 1st Faculty of Medicine of Charles \\ University and Central Military Hospital - Military University Hospital in Prague, Prague, Czech Republic \\ ${ }^{4}$ University of South Bohemia in České Budějovice, Faculty of Health and Social Sciences, Institute of Physiotherapy and Selected Medical Disciplines, \\ České Budějovice, Czech Republic
}

\section{Abstract}

Introduction: Stroke is one of the leading causes of death and disability in European countries. Prevention and the associated health literacy are among the effective tools for reducing the incidence of this disease and serve to reduce its consequences.

Goal: To examine the relationship between socioeconomic factors of health literacy and modifiable risk factors in connection with ischemic stroke.

Methods: A quantitative survey strategy. The research was conducted using the technique of a standardized controlled interview between the interviewer and the respondent. The research group included 1,004 citizens. A combination of a standardized overall health literacy questionnaire (HLSQ-16) and a non-standardized stroke prevention questionnaire was used to collect data.

Results: Most citizens of the Czech Republic (58.5\%) have sufficient health literacy. Problematic health literacy is reported by $29.2 \%$ of respondents. The remaining $13.3 \%$ of respondents have inadequate health literacy. Nevertheless, the results show that a large part of the population has problematic health literacy in areas such as good lifestyle, smoking, alcohol consumption and, last but not least, physical activity.

Conclusions: Recognition of these factors can then be suitable for preventive measures. Effective interventions focused directly on risk factors will enable a change in the thinking and attitudes of risky groups of the population.
\end{abstract}

Keywords: Health literacy; Intervention; Risk factors; Stroke

\section{Introduction}

Ischemic stroke (IS) is one of the leading causes of death and disability in Europe. In 2017, 2.3 million new cases of stroke occurred in the European Union (EU) - 54 member states, with a higher incidence in Eastern European and North African countries (Timmis et al., 2020). Bryndziar et al. (2017) mention that the presented data show stroke mortality, not its incidence. Current registries do not work with non-fatal and non-hospitalized cases of stroke (Bryndziar et al., 2017). It should be mentioned that there is convincing evidence that preventive and timely treatment interventions can reduce the effects of a stroke, including its long-term consequences (Norrving et al., 2018).

Stroke prevention involves both pharmacological and non-pharmacological interventions (Sarikaya et al., 2015). This fact is already confirmed by the INTERSTROKE study
(O’Donnell et al., 2010). Its authors described 10 risk factors that explain more than $88.1 \%$ of all cases of stroke. The results of the study show that risk factors with a strong correlation to ischemic stroke include quantified risk factors: hypertension (160/90 and above $\mathrm{mmHg}$ ), smoking, increased waist-to-hip ratio, diet, insufficient physical activity, diabetes mellitus, excessive alcohol intake, psychosocial stress, depression, cardiogenic causes, and increased values of the ratio of alipoproteins B to A1 (O'Donnell et al., 2010). However, we cannot neglect the level of socio-economic factors, education, and gender (Choudhury et al., 2015). The evidence of the modification of risk factors in the primary stroke prevention has a comparable impact to successfully treated patients for hypertension or dyslipidemia (Goff et al., 2014; Piepoli et al., 2016). Hypertension, dyslipidemia, diabetes mellitus, a high-fat diet (more than $30 \%$ of total energy intake), low physical activity, and atrial fibrillation are the strongest modifiable risk factors for stroke (GBD 2016 Risk Factors Collaborators, 2017; Stevens et al., 2017).

\footnotetext{
* Corresponding author: Lenka Šedová, University of South Bohemia in České Budějovice, Faculty of Health and Social Sciences, Institute of Nursing, Midwifery and Emergency Care, U Výstaviště 26, 37005 České Budějovice, Czech Republic; e-mail: lsedova@zsf.jcu.cz; http://doi.org/10.32725/kont.2021.024 
Influencing the risk factors of a stroke is closely related to self-management. Currently, a number of IT technologies are penetrating this area, which can significantly contribute to the improvement of the final state of health literacy (HL) and prevention in the population (Berkman et al., 2010). Health literacy is the ability to obtain, read, understand and use health information so that a person can make the right decisions about their health (Action Plan for the Development of Health Literacy, 2014). The level of HL is influenced by various determinants. The most frequently mentioned are education, age, and socio-economic factors (WHO, 2013). An important argument for dealing with this issue are the results of various studies that prove problematic and completely inadequate health literacy in a relatively large part of the adult population (Kučera et al., 2016; Nurjanah et al., 2015; Tiller et al., 2015).

Primary and secondary stroke prevention is highlighted in a number of strategic documents (Helsingborg Declaration; European Stroke Action Plan 2018-2030 - ESAP) (Norrving et al., 2018). There are differences between European countries in the level of primary prevention. The setting of primary stroke prevention is currently regulated differently in each country and there are no uniform guidelines that would oblige states to at least meet the minimum requirements (Pandian et al., 2018).

Our goal was to determine the relationship between socioeconomic factors of health literacy and modifiable risk factors regarding ischemic stroke.

\section{Materials and methods}

In the first phase of the grant project, a quantitative sociological survey was conducted. The goal was to monitor HL regarding stroke in a representative sample of the population. The preliminary research that was used to verify the instruments and individual questions included 112 citizens in September 2019. The actual field survey was conducted from November to December 2019.

The field survey was conducted using a standardized controlled interview. The final form of the interview sheet was determined on the basis of the results of the pilot research. The research was anonymous, participation was voluntary, and the survey did not contain any controversial ethical issues. A combination of a non-standardized questionnaire on stroke prevention and an abbreviated version of the Health Literacy Survey - HLS-EU-Q47 validated in the Czech population was used for data collection (Kučera et al., 2016). The evaluation of the questionnaires (HLSQ-16) creates 3 categories of health literacy: inadequate ( $0-8$ points); problematic ( $9-12$ points) and adequate (13-16 points). Only questionnaires where all questions were answered, specifically (the answer "I do not know" was not considered specific), were assessed. After the optical inspection, 705 completed questionnaires were assessed (299 questionnaires were not completed).

From the non-standardized part of the questionnaire, we selected items that were related to the IS risk factors. These were questions focused on regular smoking (one or more cigarettes a day), consumption of fish meat, fruit, and vegetables, fried foods, walking for at least 30 minutes a day (answer categories: not at all; 1-2 times a week; 3-4 times a week; 5-6 times a week; every day; several times a day). The analysis was based on 1,004 completed questionnaires.

The sample group of respondents was constructed by quota selection so that its structure corresponded to the composition of all citizens of the Czech Republic in terms of regions, gender and age. These characters were determined to be representative. The quota selection was made according to representative features.

Statistical data processing was performed using the SASD 1.4.12 (Statistical Analysis of Social Data) and SPSS programmes. The 1st level of classification and contingency tables of selected indicators of the 2nd level of classification were processed. Tests of Normality were tested using Kolmogorov-Smirnov and Shapiro-Wilk tests. Depending on the nature of this distribution and the nature of the characters, the ChiSquare Test was applied for statistical significance calculations.

\section{Results}

A total of 1,137 selected citizens were contacted, and 133 respondents $(11.7 \%)$ refused the interview. Thus, the research group consisted of 1,004 citizens (Table 1 ). The evaluation of the questionnaires (HLSQ-16) created 3 categories of health literacy: inadequate ( $0-8$ points), problematic ( $9-12$ points) and adequate (13-16 points).

The first check-up excluded 299 (30\%) questionnaires for incompleteness. 705 (70\%) completed questionnaires were analysed. From the evaluated sample, 58.5\% had adequate HL, $29.2 \%$ had problematic and $13.3 \%$ had inadequate HL.

The differences in the levels of HL regarding gender were not significant (Table 2). Health literacy was tested depending on selected socioeconomic factors. These were gender, age,

\section{Table 1. Composition of the sample group of citizens by} gender, age, residence, occupation and education

\begin{tabular}{|c|c|c|}
\hline Gender & $\begin{array}{l}\text { Absolute } \\
\text { number }\end{array}$ & $\%$ \\
\hline Male & 489 & 48.7 \\
\hline Female & 515 & 51.3 \\
\hline $\begin{array}{l}\text { Age } \\
\qquad \begin{array}{l}18-24 \\
24-34 \\
35-44 \\
45-54 \\
55-64 \\
65 \text { and higher }\end{array}\end{array}$ & $\begin{array}{l}80 \\
161 \\
199 \\
171 \\
151 \\
242\end{array}$ & $\begin{array}{c}8 \\
16 \\
19.8 \\
17 \\
15 \\
21.4\end{array}$ \\
\hline $\begin{array}{l}\text { Residence } \\
\text { city } \\
\text { country }\end{array}$ & $\begin{array}{l}650 \\
354\end{array}$ & $\begin{array}{l}64.7 \\
35.3\end{array}$ \\
\hline $\begin{array}{l}\text { Marital status } \\
\text { single } \\
\text { partner } \\
\text { married } \\
\text { divorced; separated } \\
\text { widowed }\end{array}$ & $\begin{array}{c}158 \\
169 \\
492 \\
105 \\
96\end{array}$ & $\begin{array}{c}15.7 \\
16.8 \\
49 \\
10.5 \\
9.6\end{array}$ \\
\hline $\begin{array}{l}\text { Employment } \\
\text { full-time employee } \\
\text { part-time employee } \\
\text { entrepreneur, self-employed } \\
\text { disabled pensioner } \\
\text { old age pensioner } \\
\text { other employment }\end{array}$ & $\begin{array}{c}486 \\
74 \\
90 \\
31 \\
247 \\
76\end{array}$ & $\begin{array}{c}48.4 \\
7.4 \\
9 \\
3.1 \\
24.6 \\
7.6\end{array}$ \\
\hline $\begin{array}{l}\text { Education } \\
\text { primary } \\
\text { trained, secondary education without GCSEs* } \\
\text { secondary education with GCSEs* } \\
\text { higher professional education } \\
\text { university }\end{array}$ & $\begin{array}{c}38 \\
299 \\
401 \\
68 \\
198\end{array}$ & $\begin{array}{c}3.8 \\
29.8 \\
39.9 \\
6.8 \\
19.7\end{array}$ \\
\hline
\end{tabular}


Table 2. The relationship between the health literacy of the citizens of the Czech Republic and the monitored

socio-demographic features $(n=705)$

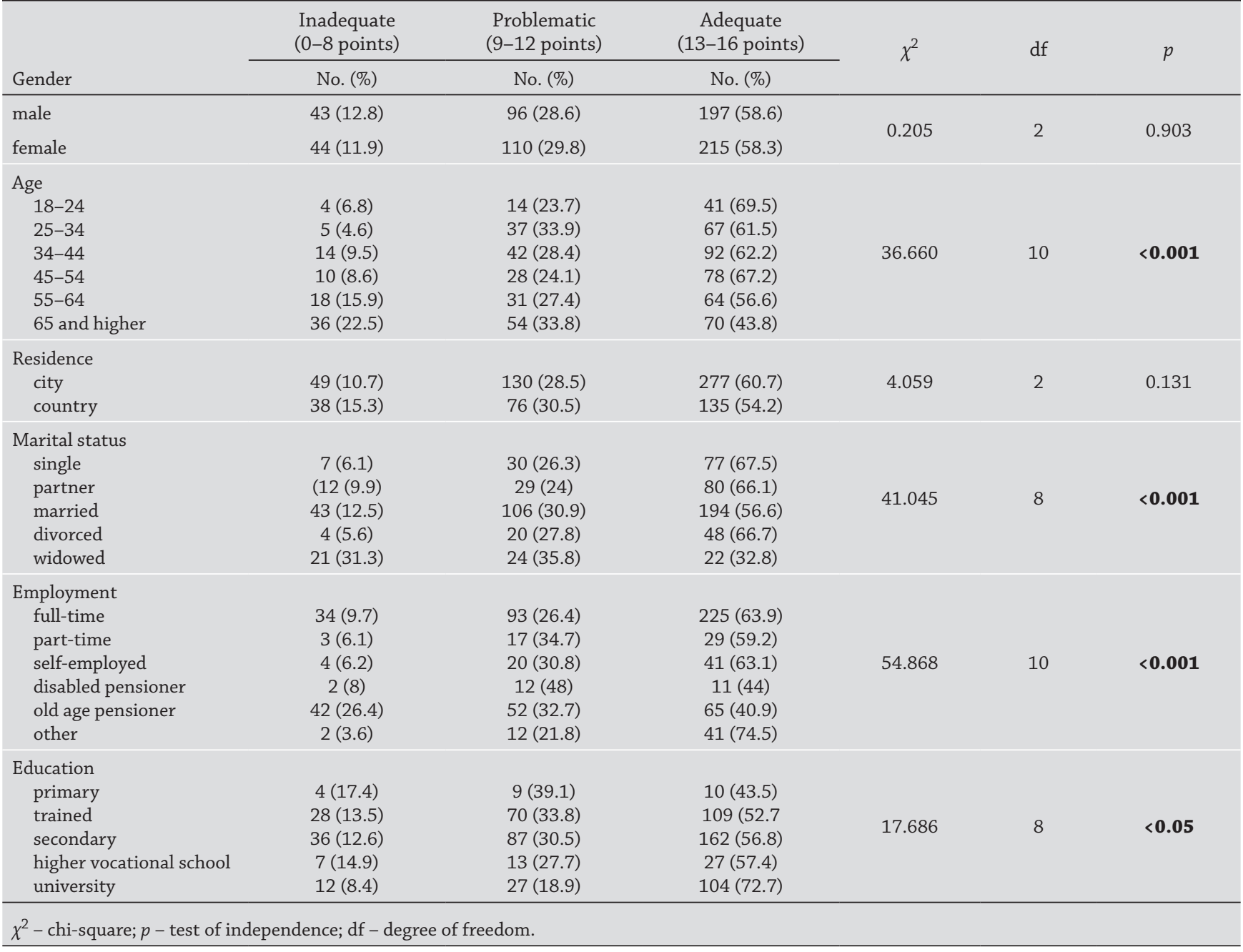

residence, marital status, employment, and education. Adequate $H L$ was found in the group aged 45-54 years, more often in people living in the city, in single people, people working full-time, and people with a university degree. People aged 25-34, people living in rural areas, widows/widowers, disability pensioners, and people with primary education more often reported problematic HL. Inadequate levels of $H L$ were reported by people over 65 , people living in the country, widows/widowers, old-age pensioners, and people with primary education. Health literacy was proven to be related to age, marital status, employment $(p<0.001)$, and education $(p<0.05)$ - Table 2 .

Table 3 presents the relationship of risk factors for stroke prevention with gender. The results show that 168 (16.7\%) people smoked at the time of the survey. Smoking was dependent on gender $(p<0.01)$, age $(p<0.01)$, marital status $(p<0.01)$, occupation $(p<0.001)$ and education $(p<0.001)$. Significantly more single people $(35 ; 20.5 \%)$ and people living in partnerships smoked $(29 ; 17 \%)(p<0.01)$. It was also found that employees $(96 ; 57.1 \%)$ and entrepreneurs $(19 ; 11.3 \%)$ smoked tobacco to a greater extent. Disabled pensioners (5; 3\%) smoked to a significantly lesser extent - Tables 4-8.

297 (29.6\%) respondents ate fish meat 1-2 times a week. Fish meat consumption was dependent on gender $(p<0.001)$, marital status $(p<0.05)$ and education $(p<0.05)$. Once or twice a week, fish meat was more frequently consumed by peo- ple with a university degree $(75 ; 25.3 \%)$, people with a secondary education more frequently ate fish meat more than twice a week $(23 ; 27.4 \%)$ - Tables $4-8$.

210 (20.9\%) people consumed fruit daily, 217 (21.6\%) consumed vegetables daily. In relation to selected socio-economic factors, the relationship between fruit consumption, sex $(p<0.001)$ and education $(p<0.001)$ was identified. Every day, women $(129 ; 61.4 \%)$ consumed fruit more frequently than men $(81 ; 38.6 \%)$, followed by people with a university degree (59; 28.1\%) - Tables 4-8.

The identification of the mutual relationship was captured in daily vegetable consumption, gender $(p<0.001)$, and education ( $p<0.01) .136$ (62.7\%) women and 81 (37.3\%) men consumed vegetables every day. Daily consumption of vegetables was more frequently preferred by people with a university degree $(63 ; 29 \%)$ - Tables 4-8.

Fried meals were consumed several times a week by 187 (18.6\%) people. Consumption of fried foods several times a week was dependent on gender $(p<0.001)$, age $(p<0.001)$, marital status $(p<0.01)$ and occupation $(p<0.05)$. In relation to the consumption of fried foods and gender, it is evident that men $(121 ; 64.7 \%)$ were more likely to choose a positive answer than women $(66$; $35.3 \%)$, followed by younger people (25-34 years) (50; $26.7 \%)$, people living in the city (133; 71.1\%), married people $(75 ; 39.9 \%)$ and old-age pensioners $(28 ; 15 \%)$ - Tables $4-8$. 
Table 3. Relationship between selected risk factors and gender $(n=1004)$

\begin{tabular}{|c|c|c|c|c|c|}
\hline & Male & Female & \multirow{2}{*}{$x^{2}$} & \multirow{2}{*}{ df } & \multirow{2}{*}{$p$} \\
\hline & No. (\%) & No. (\%) & & & \\
\hline Smoking (one or more cigarettes a day) & $95(19.4)$ & $73(14.2)$ & 10.503 & 2 & $<0.01$ \\
\hline Fish meat/products (servings) 1-2 times a week & $138(28.2)$ & $159(30.9)$ & 3.013 & 3 & 0.390 \\
\hline Daily fruit portion & $93(19.1)$ & $146(28.3)$ & 37.576 & 5 & $<0.001$ \\
\hline Daily vegetable portion & $94(19.3)$ & $153(29.7)$ & 23.679 & 5 & $<0.001$ \\
\hline Fried meals several times a week & $121(2.7)$ & $66(12.8)$ & 28.776 & 2 & $<0.001$ \\
\hline Walk for at least 30 minutes a day most days of the week (5 or more days) & $330(47.1)$ & 371 (52.9) & 2.469 & 1 & 0.120 \\
\hline
\end{tabular}

Table 4. Relationship between selected risk factors and age $(n=1004)$

\begin{tabular}{|c|c|c|c|c|c|c|c|c|c|}
\hline & $\begin{array}{c}18-24 \\
\text { years }\end{array}$ & $\begin{array}{c}25-34 \\
\text { years }\end{array}$ & $\begin{array}{c}35-44 \\
\text { years }\end{array}$ & $\begin{array}{c}45-54 \\
\text { years }\end{array}$ & $\begin{array}{c}55-64 \\
\text { years }\end{array}$ & $\begin{array}{c}65 \text { and } \\
\text { older }\end{array}$ & \multirow[t]{2}{*}{$\chi^{2}$} & \multirow[t]{2}{*}{ df } & \multirow[t]{2}{*}{$p$} \\
\hline & No. (\%) & No. $(\%)$ & No. $(\%)$ & No. $(\%)$ & No. (\%) & No. (\%) & & & \\
\hline Smoking (one or more cigarettes a day) & $9(5.4)$ & $38(22.6)$ & $30(17.9)$ & $30(17.9)$ & $28(16.7)$ & $33(19.6)$ & 29.487 & 10 & $<0.01$ \\
\hline $\begin{array}{l}\text { Fish meat/products (servings) 1-2 times } \\
\text { a week }\end{array}$ & $17(5.7)$ & $39(13.1)$ & $64(21.5)$ & $45(15.2)$ & $57(19.2)$ & $75(25.3)$ & 23.132 & 15 & 0.081 \\
\hline Daily fruit portion & $17(8.1)$ & $32(15.2)$ & $43(20.5)$ & $33(15.7)$ & $30(14.3)$ & $55(26.2)$ & 16.764 & 25 & 0.890 \\
\hline Daily vegetable portion & $16(7.4)$ & $36(16.6)$ & $46(21.2)$ & $39(18)$ & $31(14.3)$ & $49(22.6)$ & 29.717 & 25 & 0.235 \\
\hline Fried meals several times a week & $21(11.2)$ & $50(26.7)$ & $35(18.7)$ & $28(15)$ & $23(12.3)$ & $30(16)$ & 36.271 & 10 & $<0.001$ \\
\hline $\begin{array}{l}\text { Walk for at least } 30 \text { minutes a day most days } \\
\text { of the week ( } 5 \text { or more days) }\end{array}$ & $66(9.4)$ & $125(17.8)$ & 155 (22.1) & $128(18.3)$ & $97(13.8)$ & $130(18.5)$ & 50.988 & 5 & $<0.001$ \\
\hline
\end{tabular}

Table 5. Relationship between selected risk factors and residence $(n=1004)$

\begin{tabular}{|c|c|c|c|c|c|}
\hline & City (570) & Country (328) & \multirow{2}{*}{$\chi^{2}$} & \multirow{2}{*}{ df } & \multirow{2}{*}{$p$} \\
\hline & No. (\%) & No. (\%) & & & \\
\hline Smoking (one or more cigarettes a day) & $118(70.2)$ & $50(29.8)$ & 3.733 & 2 & 0.155 \\
\hline Fish meat/products (servings) 1-2 times a week & $201(67.7)$ & $96(32.3)$ & 5.792 & 3 & 0.122 \\
\hline Daily fruit portion & $143(68.1)$ & $67(31.9)$ & 8.867 & 5 & 0.115 \\
\hline Daily vegetable portion & $137(63.1)$ & $80(36.9)$ & 7.732 & 5 & 0.172 \\
\hline Fried meals several times a week & $133(71.1)$ & $54(28.9)$ & 5.220 & 2 & 0.074 \\
\hline Walk for at least 30 minutes a day most days of the week ( 5 or more days) & $462(65.9)$ & $239(34.1)$ & 1.381 & 1 & 0.244 \\
\hline
\end{tabular}

\section{Table 6. Relationship between selected risk factors and marital status $(n=1004)$}

\begin{tabular}{|c|c|c|c|c|c|c|c|c|}
\hline & 1.* $(120)$ & 2.* $(140)$ & 3.* (451) & 4. ${ }^{*}(107)$ & $5 .^{*}(96)$ & \multirow{2}{*}{$\chi^{2}$} & \multirow{2}{*}{ df } & \multirow{2}{*}{$p$} \\
\hline & No. $(\%)$ & No. (\%) & No. (\%) & No. (\%) & No. (\%) & & & \\
\hline Smoking (one or more cigarettes a day) & $35(20.5)$ & $29(17)$ & $73(42.7)$ & $23(13.5)$ & $11(6.4)$ & 21.697 & 8 & $<0.01$ \\
\hline Fish meat/products (servings) 1-2 times a week & $36(12)$ & $42(14)$ & $158(52.7)$ & $30(10)$ & $34(11.3)$ & 22.792 & 12 & $<0.05$ \\
\hline Daily fruit portion & $30(14)$ & $35(16.3)$ & $114(53)$ & $20(9.3)$ & $16(7.4)$ & 14.206 & 20 & 0.820 \\
\hline Daily vegetable portion & $27(12.3)$ & $31(14.1)$ & $120(54.5)$ & $26(11.8)$ & $16(7.3)$ & 27.682 & 20 & 0.117 \\
\hline Fried meals several times a week & 36 (19.1) & $40(21.3)$ & 75 (39.9) & $26(13.8)$ & $11(5.9)$ & 22.953 & 8 & $<0.01$ \\
\hline $\begin{array}{l}\text { Walk for at least } 30 \text { minutes a day most days of the } \\
\text { week ( } 5 \text { or more days) }\end{array}$ & 125 (17.5) & $130(18.2)$ & $342(47.9)$ & $67(9.4)$ & $50(7)$ & 26.753 & 4 & $<0.001$ \\
\hline
\end{tabular}


Table 7. Relationship between selected risk factors and employment $(n=1004)$

\begin{tabular}{|c|c|c|c|c|c|c|c|c|c|}
\hline & 1.* $(428)$ & 2.* (72) & 3.* (75) & 4.* (35) & 5.* (231) & 6.* (57) & \multirow{2}{*}{$x^{2}$} & \multirow{2}{*}{ df } & \multirow{2}{*}{$p$} \\
\hline & No. (\%) & No. (\%) & No. (\%) & No. (\%) & No. (\%) & No. (\%) & & & \\
\hline Smoking (one or more cigarettes a day) & $96(57.1)$ & $7(4.2)$ & 19 (11.3) & $5(3)$ & $32(19)$ & $9(5.4)$ & 32.690 & 10 & $<0.001$ \\
\hline $\begin{array}{l}\text { Fish meat/products (servings) 1-2 times } \\
\text { a week }\end{array}$ & 135 (45.5) & $19(6.4)$ & $29(9.8)$ & $13(4.4)$ & 81 (27.3) & $20(6.7)$ & 12.740 & 15 & 0.622 \\
\hline Daily fruit portion & $102(48.6)$ & $15(7.1)$ & $17(8.1)$ & & $54(5.4)$ & $19(9)$ & 28.253 & 25 & 0.296 \\
\hline Daily vegetable portion & $107(49.3)$ & $17(7.8)$ & $21(9.7)$ & $3(1.4)$ & $51(23.5)$ & $18(8.3)$ & 20.574 & 25 & 0.716 \\
\hline Fried meals several times a week & $97(51.9)$ & $18(9.6)$ & $20(10.7)$ & $5(2.7)$ & $28(15)$ & $19(10.2)$ & 18.833 & 10 & $<0.05$ \\
\hline $\begin{array}{l}\text { Walk for at least } 30 \text { minutes a day most days } \\
\text { of the week ( } 5 \text { or more days) }\end{array}$ & $370(52.8)$ & $61(8.7)$ & $58(8.3)$ & $16(2.3)$ & 132 (18.8) & 64 (9.1) & 59.801 & 5 & $<0.001$ \\
\hline
\end{tabular}

*1. full-time employee; 2. part-time employee; 3. self-employed; 4. disabled pensioner; 5. old-age pensioner; 6 . other.

$\chi^{2}$ - chi-square; $p$ - test of independence; $\mathrm{df}$ - degree of freedom.

Table 8. Relationship between selected risk factors and education $(n=1004)$

\begin{tabular}{|c|c|c|c|c|c|c|c|c|}
\hline & $\begin{array}{l}\text { Primary } \\
(27)\end{array}$ & $\begin{array}{l}\text { Trained } \\
(257)\end{array}$ & $\begin{array}{l}\text { Secondary } \\
(360)\end{array}$ & $\begin{array}{l}\text { Vocational } \\
(60)\end{array}$ & $\begin{array}{l}\text { University } \\
\text { (194) }\end{array}$ & \multirow[t]{2}{*}{$\chi^{2}$} & \multirow[t]{2}{*}{ df } & \multirow{2}{*}{$p$} \\
\hline & No. (\%) & No. (\%) & No. (\%) & No. (\%) & No. (\%) & & & \\
\hline Smoking (one or more cigarettes a day) & $4(2.4)$ & $69(41.1)$ & $58(34.5)$ & $15(8.9)$ & $22(13.1)$ & 30.754 & 8 & $<0.001$ \\
\hline Fish meat/products (servings) 1-2 times a week & $7(2.4)$ & $85(28.6)$ & $112(37.7)$ & $18(6.1)$ & $75(25.3)$ & 25.437 & 12 & $<0.05$ \\
\hline Daily fruit portion & $9(4.3)$ & $43(20.5)$ & $84(40)$ & $15(7.1)$ & $59(28.1)$ & 56.430 & 20 & $<0.001$ \\
\hline Daily vegetable portion & $9(4.1)$ & $51(23.5)$ & $80(36.9)$ & $14(6.5)$ & $63(29)$ & 40.460 & 20 & $<0.01$ \\
\hline Fried meals several times a week & $6(3.2)$ & $53(28.3)$ & $85(45.5)$ & $9(4.8)$ & $34(18.2)$ & 11.635 & 8 & 0.168 \\
\hline $\begin{array}{l}\text { Walk for at least } 30 \text { minutes a day most days of the } \\
\text { week ( } 5 \text { or more days) }\end{array}$ & $28(4)$ & $202(28.8)$ & $277(39.5)$ & $56(8)$ & $138(19.7)$ & 6.170 & 4 & 0.187 \\
\hline
\end{tabular}

\section{Discussion}

In the Czech Republic, there are studies describing the state of HL in the population (Bártlová et al., 2018; Holčík, 2009; 2010; 2017a, b; Kučera et al., 2016). None of them deal with the association with the health condition of the population. The relationship between health literacy and ischemic stroke has not yet been described in the Czech Republic. However, we can assume that the importance of HL is high, as stroke is associated with a number of modifiable risk factors (O'Donnell et al., 2010). It should be noted that HL is not only about knowledge but also about the application of acquired information to maintain and improve the level of health (Sørensen et al., 2012; WHO, 2013). Thus, it can be assumed that the more people know the risk factors of IS and are able to apply this information to their daily lives, the better their HL will be.

Tiller et al. (2015) report in their study that adults with better health had significantly higher health literacy. With this in mind, they present an interesting idea and argue that people with lower levels of health literacy may have a higher risk of stroke in the future.

Patients with insufficient HL have a lower understanding of their health, which is also associated with non-use of preventive services, delayed diagnosis of the disease, low self-management, lack of understanding of medical guidelines, and adherence to treatment (Bennett et al., 2009; Rudd, 2015). The obtained results of the presented study show that half of the respondents have sufficient health literacy (58.5\%), which is a similarly high level of HL as in the German CARLA study (Tiller et al., 2015). The context analysis shows that health literacy in our cohort depends on age, marital status, employment, and education. The research analysis of Stormacq et al. (2019) concludes that disadvantaged social and socioeconomic factors contribute to low HL, while low socioeconomic status and educational attainment are the most important determinants of HL. Thus, HL can be considered as a modifiable risk factor of socioeconomic differences in health. In our study, people over the age of 65 , as well as widows and widowers, disabled and old-age pensioners, and people with primary education showed lower HL. Increasing HL in the population or making health services available to people with lower HL can be a means of reducing health inequalities.

The evaluation of other modifiable risk factors for ischemic stroke is an integral part of health literacy. In the questionnaire survey, we focused on the issue of smoking, consumption of fish meat, fruits and vegetables, and physical activities. The results were compared with selected socioeconomic factors. There were a total of $16.8 \%$ of smokers in our group. Another analysis showed that men, young people, people living in cities, and married people or employees smoked more often. Furthermore, there was a connection with the level of education. The research of the State Health Institute from 2015 points to the fact that in 2015 there were $24.1 \%$ of smokers in the Czech Republic, which is a significant decrease compared to 2014 (by $6.2 \%$ ). At the same time, they also talk about the 
fact that smoking in the Czech Republic accounts for 17-19\% of total mortality (Sovinová and Csémy, 2016). The evidence of cigarette smoke affecting stroke is convincing. Smokers have a two- to four-fold higher risk of stroke compared to non-smokers (Shah and Cole, 2010). Tobacco smoke inflicts damage on the vascular wall (Qureshi et al., 2005). Due to the effects of cigarette smoke, there is a loss of anti-profiling, anti-thrombogenic effects, and negative changes in hemocoagulation processes (Vrablík et al., 2004). According to Králíková (2011), short interventions led by nurses in practice can help in quitting smoking.

The specifics of diet are closely related to stroke incidence, as is evident from current recommendations, especially in relation to hypertension, which is associated with excessive sodium intake, decreased potassium intake and alcohol consumption (Appel et al., 2006; 2012). American recommendations (American Heart Association, American Stroke Association) summarize recommendations such as reducing sodium and increasing potassium intake to lower blood pressure, DASH diet or a Mediterranean-type diet with increased fruit and vegetable intake and reduced fat intake (Meschia et al., 2014). In our group, women consumed fruits and vegetables on a daily basis more than men. It is also clear that regular consumption correlated with the level of education. Regular exercise is an integral part of every person's lifestyle. For our research, we asked whether people spent most of their days (5 or more) a week walking for at least 30 minutes. The results show that walking correlated with age, marital status, and occupation. A meta-analysis of Wendel-Vos et al. (2004) shows that physically active men and women generally have a $25-30 \%$ lower risk of stroke and mortality than physically inactive people, while the benefits of physical activity in spending free time, work or walking are equally effective. The relationship between health literacy and physical activity is reported by Gibney and Doyle (2017), where the results of their research show a lower level of health literacy in people who do not exercise regularly.

Lifestyle adjustment is an interesting phenomenon in stroke prevention, as the incidence of strokes has decreased by as much as $42 \%$ in developed countries over the past 30 years, while it has increased by $100 \%$ in developing countries (Hankey, 2012). The strength of stroke risk factors, such as dietary recommendations, motivation for quitting smoking, physical activity, alcohol consumption, and overweight or obesity, is supported by the results of observational studies (Sarikaya et al., 2015). For example, the results of prospective cohort studies of the Health Professionals Follow-up Study and the Nurses' Health Study show that lifestyle change is more beneficial than treating risk factors. Respondents in these studies who followed the recommendations (quitting smoking, regular walking for at least 30 minutes a day, a balanced diet, limited alcohol consumption, and BMI up to $25 \mathrm{~kg} / \mathrm{m} 2$ ) had an $80 \%$ lower risk of stroke than non-adherents (Chiuve et al. al., 2008).

The tool for improving the level of HL and risk factors for IS is the education of patients in lifestyle management. It is man- aged by doctors and nurses in primary and secondary health care. Education is not a matter of passive information. As reported by Nielsen-Bohlman et al. (2004), there is an increasing emphasis on patients being active participants in the care of their own health, not just passive recipients. We refer to the level of cooperation as "compliance". Greater potential in this area is represented by nurses, who usually have a greater overview of how the patient reacts to change, what progress he/ she is making or what barriers he/she is facing. Foreign studies in which nurses manage educational interventions differ in the length of education, educational strategies, and methods. What they have in common is that education must take place repeatedly and regularly, in longer educational units, most of which show an effect not only in increasing awareness of the disease but also in improving diet, medication "compliance" and exercise regime (Flemming et al., 2013; Goldfinger et al., 2012; Kronish et al., 2014; Parappilly et al., 2018). Such programmes can help to improve the long-term control of IS risk factors and to improve HL.

The positives of the work include the fact that it was implemented on a representative sample group of the population in the Czech Republic and the data obtained can be generalized to the citizens of the Czech Republic in terms of regions, gender, and age. The limitations were the unrepresentativeness of some sociodemographic features, and bias in the form of a significant proportion of discarded questionnaires due to incompleteness in the HL questionnaires.

\section{Conclusions}

The results of the research show that the citizens of the Czech Republic have adequate health literacy. The degree of HL depends on age, marital status, occupation, and education. Lower HL was found in persons over 65 years of age, widows and widowers, disabled and old-age pensioners, and persons with primary education. In the population of the Czech Republic, a high proportion of regular smokers remains (approx. 17\%), $2 / 3$ of people do not have regular and sufficient consumption of fruit, vegetables, and fish meat, half of them lack sufficient and regular fitness physical activity. The results of the research reveal insufficient education about the prevention of IS. Physicians and nurses in primary and secondary health care should make more use of continuous education tools to improve comprehensive health care for people at high risk and people undergoing treatment after IS.

\section{Conflict of interests}

The authors have no conflict of interests to declare.

\section{Acknowledgements}

Supported by the Ministry of Health of the Czech Republic, grant nr. NV19-09-00199. All rights reserved. 


\section{Zdravotní gramotnost a ovlivnitelné rizikové faktory cévní mozkové přihody}

\section{Souhrn}

Úvod: Cévní mozková příhoda (CMP) patří mezi hlavní př́íciny smrti a postižení v evropských zemích. Prevence a s ní spojovaná zdravotní gramotnost patří mezi efektivní nástroje snižování výskytu tohoto onemocnění a slouží k případnému snižování jejích následků.

Cíl: Vztah socioekonomických faktorů zdravotní gramotnosti a ovlivnitelných rizikových faktorů v souvislosti s ischemickou CMP. Metodika: Šlo o kvantitativní strategii šetření, výzkum byl proveden technikou standardizovaného řízeného rozhovoru tazatele s respondentem. Výzkumný soubor tvořilo 1004 občanů. Ke sběru dat byla použita kombinace standardizovaného dotazníku pro zjištění celkové zdravotní gramotnosti (HLSQ-16) a nestandardizovaného dotazníku týkajícího se prevence cévní mozkové př́hody.

Výsledky: Většina občanů České republiky $(58,5$ \%) má dostatečnou zdravotní gramotnost. Problematickou zdravotní gramotnost vykazuje 29,2 \% dotázaných, zbývajících 13,3 \% respondentů má zdravotní gramotnost neadekvátní. Přesto však výsledky prokazují, že značná část obyvatelstva vykazuje problematickou zdravotní gramotnost v oblastech, jako jsou správná životospráva, kouření, konzumace alkoholických nápojů a v neposlední řadě v pohybové aktivitě.

Závěr: Rozpoznání těchto faktorů je pak možné vsadit do oblastí preventivního působení. Efektivní intervence zaměřené přímo na rizikové faktory umožní změnu v myšlení a postojích rizikových skupin obyvatel.

Klíčová slova: cévní mozková příhoda; intervence; rizikové faktory; zdravotní gramotnost

\section{References}

1. Action Plan for the Development of Health Literacy (2014). In: Zdraví 2020 - Národní strategie ochrany a podpory zdraví a prevence nemocí. Pracovní skupina č. 12. Praha: MZ ČR.

2. Appel LJ, Angell SY, Cobb LK, Limper HM, Nelson DE, Samet JM, Brownson RC (2012). Population-wide sodium reduction: the bumpy road from evidence to policy. Ann Epidemiol 22(6): 417-425. DOI: 10.1016/j.annepidem.2012.04.003.

3. Appel LJ, Brands MW, Daniels SR, Karanja N, Elmer PJ, Sacks FM (2006). Dietary approaches to prevent and treat hypertension: a scientific statement from the American Heart Association. Hypertension 47(2): 296-308. DOI: 10.1161/01. HYP.0000202568.01167.B6.

4. Bártlová S, et al. (2018). Zdravotní gramotnost u vybraných skupin obyvatelstva Jihočeského kraje. Praha: Grada Publishing, $176 \mathrm{p}$.

5. Bennett IM, Chen J, Soroui JS, White S (2009). The contribution of health literacy to disparities in self-rated health status and preventive health behaviors in older adults. Ann Fam Med 7(3): 204-211. DOI: 10.1370/afm.940.

6. Berkman ND, Davis TC, McCormack L (2010). Health literacy: what is it? J Health Commun 15(Suppl. 2): 9-19. DOI: $10.1080 / 10810730.2010 .499985$.

7. Bryndziar T, Šedová P, Mikulík R (2017). Incidence cévní mozkové příhody v Evropě - systematická review. Cesk Slov Neurol 80/113(2): 180-189. DOI: 10.14735/amcsnn2017180.

8. Chiuve SE, Rexrode KM, Spiegelman D, Logroscino G, Manson JE, Rimm EB (2008). Primary prevention of stroke by healthy lifestyle. Circulation 118(9): 947-954. DOI: 10.1161/ CIRCULATIONAHA.108.781062.

9. Choudhury MS, Chowdhury MD, Nayeem A, Jahan WA (2015). Modifiable and Non-Modifiable Risk Factors of Stroke: A Review Update. Journal of National Institute of Neurosciences Bangladesh 1(1): 22-26. DOI: 10.3329/jninb.v1i1.22944.

10. GBD 2016 Risk Factors Collaborators (2017). Global, regional, and national comparative risk assessment of 84 behavioural, environmental and occupational, and metabolic risks or clusters of risks, 1990-2016: a systematic analysis for the Global Burden of Disease Study 2016. Lancet 390(10100): 1345-1422. DOI: 10.1016/0140-6736(17)32366-8.

11. Gibney S, Doyle G (2017). Self-rated Health Literacy is Associated with Exercise Frequency Among Adults Aged 50+ in Ireland. Eur J Public Health 27(4): 755-761. DOI: 10.1093/ eurpub/ckx028.
12. Goff DC, Jr., Lloyd-Jones DM, Bennett G, Coady S, D'Agostino RB, Gibbons R, et al. (2014). 2013 ACC/AHA guideline on the assessment of cardiovascular risk: a report of the American College of Cardiology/American Heart Association Task Force on Practice Guidelines. Circulation 129(25 Suppl. 2): S49-73. DOI: 10.1161/01.cir.0000437741.48606.98.

13. Goldfinger JZ, Kronish IM, Fei K, Graciani A, Rosenfeld P, Lorig K, Horowitz CR (2012). Peer education for secondary stroke prevention in inner-city minorities: Design and methods of the prevent recurrence of all inner-city strokes through education randomized controlled trial. Contemp Clin Trials 33(5): 1065-1073. DOI: 10.1016/j.cct.2012.06.003.

14. Flemming KD, Allison TG, Covalt JL, Herzig DE, Brown RD (2013). Utility of a Post-Hospitalization Stroke Prevention Program Managed by Nurses. Hosp Pract 41(3): 70-79. DOI: $10.3810 / \mathrm{hp} .2013 .08 .1070$.

15. Hankey GJ (2012). Nutrition and the risk of stroke. Lancet Neurol 11(1): 66-81. DOI: 10.1016/S1474-4422(11)70265-4.

16. Holčík J (2009). Zdravotní gramotnost a její role v péči o zdraví: k teoretickým základům cesty ke zdraví. Brno: MSD, 149 p.

17. Holčík J (2010). Systém péče o zdraví a zdravotní gramotnost: k teoretickým základům cesty ke zdraví. Brno: Masarykova univerzita, $293 \mathrm{p}$.

18. Holčík J (2017a). Zdravotní gramotnost je prioritou péče o zdraví 1. část. In: Ústav pro zdravotní gramotnost. 1. národní konference o zdravotní gramotnosti (situační dokument). Praha: UHL.

19. Holčík J (2017b). Zdravotní gramotnost a zdravotní politika. Sborník textů pro kolokvium. Praha: Ústav pro zdravotní gramotnost, z. ú.

20. Králíková E (2011). Jak pomoci pacientům přestat koư̌it. Interní Med 13(11): 453-454.

21. Kronish IM, Goldfinger JZ, Negron R, Fei K, Tuhrim S, Arniella G, Horowitz CR (2014). Effect of peer education on stroke prevention: the prevent recurrence of all inner-city strokes through education randomized controlled trial. Stroke 45(11): 3330-3336. DOI: 10.1161/STROKEAHA.114.006623.

22. Kučera Z, Pelikan J, Šteflová A (2016). Zdravotní gramotnost obyvatel ČR. Výsledky komparativního reprezentativního šetření. Čas Lék čes 155(5): 233-241.

23. Meschia JF, Bushnell C, Boden-Albala B, Braun LT, Bravata DM, Chaturvedi S, et al. (2014). Guidelines for the Primary Prevention of Stroke A Statement for Healthcare Professionals From the American Heart Association/American Stroke Association. Stroke 45(12): 3754-3832. DOI: 10.1161/ STR.0000000000000046. 
24. Nielsen-Bohlman L, Panzer AM, Kindig DA (Eds) (2004). Health literacy: A Prescription to End Confusion. Washington (DC): National Academies Press. DOI: 10.17226/10883.

25. Norrving B, Barrick J, Davalos A, Dichgans M Cordonnier C, Guekht A, et al. (2018). Action Plan for Stroke in Europe 2018-2030. Eur Stroke J 3(4): 309-336. DOI: $10.1177 / 2396987318808719$.

26. Nurjanah N, Rachmany E, Manglapy YM (2015). Assessing Health Literacy on Student Using Online HLS-EU-16. In: International Seminar on Public Health and Education, 23rd April. Indonesia.

27. O’Donnell M, Xavier D, Diener C, Sacco R, Lisheng L, Zhang H, et al. (2010). Rationale and design of INTERSTROKE: a global case-control study of risk factors for stroke. Neuroepidemiology 35(1): 36-44. DOI: 10.1159/000306058.

28. Pandian JD, Gall SL, Kate MP, Silva GS, Akinyemi RO, Ovbiagele BI, et al. (2018). Prevention of stroke: a global perspective. Lancet 392(10154): 1269-1278. DOI: 10.1016/ S0140-6736(18)31269-8.

29. Parappilly BP, Field TS, Mortenson WB, Sakakibara BM, Eng JJ (2018). Effectiveness of interventions involving nurses in secondary stroke prevention: A systematic review and meta-analysis. Eur J Cardiovasc Nurs 17(8): 728-736. DOI: $10.1177 / 1474515118779732$.

30. Piepoli MF, Hoes AW, Agewall S, Albus Ch, Brotons C, Catapano AL, et al. (2016). 2016 European Guidelines on cardiovascular disease prevention in clinical practice: the Sixth Joint Task Force of the European Society of Cardiology and Other Societies on Cardiovascular Disease Prevention in Clinical Practice (constituted by representatives of 10 societies and by invited experts) developed with the special contribution of the European Association for Cardiovascular Prevention \& Rehabilitation (EACPR). Eur Heart J 37(29): 2315-2381. DOI: 10.1093/eurheartj/ehw106.

31. Qureshi AI, Suri MF, Kirmani JF, Divani AA (2005). Cigarette smoking among spouses: another risk factor for stroke in women. Stroke 36(9): e74-e76. DOI: 10.1161/01. STR.0000177475.30281.7f

32. Rudd RE (2015). The evolving concept of Health literacy: New directions for health literacy studies. J Commun Healthc 8(1): 7-9. DOI: 10.1179/1753806815Z.000000000105.
33. Sarikaya H, Ferro J, Arnold M (2015). Stroke prevention medical and lifestyle measures. Eur Neurol 73(3-4): 150-157. DOI: 10.1159/000367652.

34. Shah RS, Cole JW (2010). Smoking and stroke: the more you smoke the more you stroke. Expert Rev Cardiovasc Ther 8(7): 917-932. DOI: 10.1586/erc.10.56.

35. Sørensen K, Van den Broucke S, Fullam J, Doyle G, Pelikan J, Slonska Z, Brand H (2012). Health literacy and public health: A systematic review and integration of definitions and models. BMC Public Health 12(80). DOI: 10.1186/1471-2458-12-80.

36. Sovinová H, Csémy L (2016). Užívání tabáku v České republice 2015. Praha: Státní zdravotní ústav.

37. Stevens E, Emmett E, Wang Y, McKevitt C, Wolfe C (2017). The burden of stroke in Europe. London: Stroke Alliance for Europe (SAFE), $131 \mathrm{p}$

38. Stormacq C, Van den Broucke S, Wosinski J (2019). Does health literacy mediate the relationship between socioeconomic status and health disparities? Integrative review. Health Promot Int 34(5): e1-e17. DOI: 10.1093/heapro/day062.

39. Tiller D, Herzog B, Kluttig A, Haerting J (2015). Health literacy in an urban elderly East-German population - results from the population-based CARLA study. BMC Public Health 15(1): 883. DOI: 10.1186/s12889-015-2210-7.

40. Timmis A, Townsend N, Gale CP, Torbica A, Lettino M, Petersen SE, et al. (2020). European Society of Cardiology: Cardiovascular Disease Statistics 2019. Eur Heart J 41(1): 12-85. DOI: 10.1093/eurheartj/ehz859.

41. Vrablík M, Králíková E, Češka R (2004). Koư̌ení a kardiovaskulární onemocnění se zaměřením na metabolizmus lipidů. Kardiologická revue 4: 166-169.

42. Wendel-Vos GCW, Schuit AJ, Feskens EJM, Boshuizen HC, Verschuren WMM, Saris WHM, Kromhout D (2004). Physical activity and stroke: a meta-analysis of observational data. Int J Epidemiol 33(4): 787-798. DOI: 10.1093/ije/dyh168.

43. WHO - World Health Organization (2013). Health literacy: The solid facts, $73 \mathrm{p}$. 